\title{
Process Costs and Error Costs: The Reform of Civil Appeals in Anglo-American Perspective
}

\begin{abstract}
By Dominic J De Saulles*
Courts make "mistakes"; Correction of these "mistakes" has a private and public purpose. The appeal system exists to satisfy both of these interests. The appeal system has to hold the balance between minimising the costs caused by error and minimising the process costs of putting things right. English civil justice resources have become stretched and the court system has struggled to provide an efficient procedure for appeals. The guiding theory of 'one appeal is enough' has reinforced the importance of the permission stage but operating this is itself a drain on resources. The Court of Appeal wants to concentrate upon being a court of first appeal for the High Court. Second appeals to it will become less frequent and the role of the High Court in terms of developing the common law will be of increased significance.
\end{abstract}

Keywords: Public purpose; Private purpose; Error cost; Process cost; Leave to appeal.

\section{Introduction}

Purposes, Proportionality and Preference

Lord Phillips PSC in $R$ (Cart) v Upper Tribunal [2011] UKSC 28at paragraph [68] set out the private and public purpose ${ }^{1}$ of appeals as follows, ${ }^{2}$

'The private purpose was to correct [...]. The public purpose was to ensure public confidence [...] and [...] to clarify and develop the law, $[\ldots]$ and to $[\ldots]$ maintain $[\ldots]$ standards $[\ldots]$,

He went on to highlight the need for a measured approach to dealing with appeals saying,

'More than one level of appeal would not normally be justified unless an important point of principle or practice was involved.'

This is a very different approach to that which might be preferred by some litigants. As Roscoe Pound noted, it is of the nature of the process that parties will want to appeal. Many of these cases will involve, 'futile appeals raising

\footnotetext{
${ }^{*}$ Senior Lecturer, Cardiff School of Law and Politics, Cardiff University, Cardiff, Wales, UK.

${ }^{1}$ Samaha (2006-2007) p. $603 \mathrm{fn} 7$.

${ }^{2}$ Echoing Bowman (1997) Chap. 2, par. 12 which in turn echoes Lord Woolf (1996) Chap. 14, par. 2. For comment on Bowman see Andrews (2000) p. 464 and Jacob (1998) p. 390.
} 
questions which have been long or well settled but are earnestly argued, often in entire good faith by those who raise them. ${ }^{3}$

\section{The Need for an Appeals Process}

There is always the possibility of error in the decision of a court. The purpose of the appeals process is to allow the civil justice system to correct decisions which have been made wrongly ${ }^{4}$ and to intervene where there has been an insufficiently fair process. ${ }^{5}$ Where correctness is concerned, any one of three things may suffice to justify overturning a judicial decision on appeal: the judge being wrong on the facts; wrong in law; or wrong in the way discretion is exercised. Fairness is also important. The process has to be fair in terms of the court's own standards of procedural justice ${ }^{6}$ ) but also have some relation to wider societal notions of procedural justice. The policy worry is that people would lose faith in the civil justice system's ability to deliver justice as an outcome, with a consequent loss of standing for the system.

\section{The Intractable ${ }^{7}$ Appeals Problem}

The appeals problem is not new. ${ }^{8}$ There have been distinct threads running through attempts at appellate reform: a worry about diluting the 'quality' of the court's work; an inherent conservatism about the role of an appeal court; and a tendency to confuse process which enhances quality, for process which increases efficiency.

Sir Jack Jacob in The Fabric of English Civil Justice, ${ }^{9}$ noted that there was an inherent tension within the civil justice system because of the conflict between 'two distinct principles' namely that decisions should be both correct and just, and that decisions should be final.

This tension has not disappeared over time but the current reforms are driven primarily by a lack of money. There are currently insufficient judges in the Court of Appeal to deal with appeals in a timely manner: more parties are seeking to appeal; parties are disinclined to take 'no' for an answer; cases are becoming increasingly complex; and the way that appeals are advanced is

\footnotetext{
${ }^{3}$ Pound (1941) p. 379. See also Tanfern Ltd. v Cameron-Macdonald [2000] 1 W.L.R. 1311 at paragraph [43] for similar sentiments.

${ }^{4}$ Where, in the terminology of CPR 52.6, the decision is said to have been 'wrong.'

${ }^{5}$ In Ponamma v Arumogan [1905] AC 383 PC, Lord Davey said, at p. 390, 'the question is, whether the order of the court [...] was right on the materials which that court had before it.'

${ }^{6} \mathrm{~A}$ close cousin of the American due process of law. There it is common to distinguish between procedural due process and substantive due process. Procedural due process is akin to our procedural fairness but is constitutionally embedded.

${ }_{8}^{7}$ See Briggs (2015) p. 113.

${ }^{8}$ See Section VIII of theFinal Report of the Committee on Supreme Court Practice and Procedure, Cmd 8878, (1953, HMSO). For an American view of this see Clark (1954) p. 1046.

${ }^{9}$ Jacob (1987) p. 210.
} 
complicated, making it difficult to see the real point. ${ }^{10}$ Judges, absorbed in considering applications for permission, do not have time to identify the point in issue and focus the parties' attention accordingly. ${ }^{11}$ As a result the workload of the appeal court is increased.

So how much time and effort should an appeal court allocate to a case? This is a second order issue because an appellant is now aggrieved with the judge over his decision. ${ }^{12}$ The temptation however is to examine the whole case again because failure here would challenge the system's very raison d'être.But perfection, even if achievable, would be unaffordable. ${ }^{13}$ The resources to deal with appeals are very limited, so how best to use them? The answer is to filter out cases weak and unimportant cases. At the first level of appeals the threshold is set, largely, by a merits test. For second appeals it is set, largely, by reference to both merits and importance. ${ }^{14}$

\section{Restriction, Protection and Finality}

The search for a win (not 'justice" ${ }^{15}$ ) has a habit of driving people to take a case as far as it will go. Some people will not accept that they should have lost ${ }^{16}$ and a limit on appeals may be justified on the basis of protecting parties from themselves. ${ }^{17}$ The CPR 52.6 threshold test (for first appeals) and the CPR 52.7 threshold test (for second appeals) can help here. These procedures should also help to control the person who has lost all objectivity and become the unreasonable litigant. ${ }^{18}$

The appeal is aimed at depriving the respondent of the fruits of his judgment in which he has invested money, time and effort. This is where Jacob's principle of finality comes into play. Finality is seen as important because of the disruption that disputes are believed to cause within society. Disputes are seen as an 'evil', the adversarial system recognising the value of imposed peace; as Lord Simon said in The Ampthill Peerage Case

\footnotetext{
${ }^{10}$ This is actually an efficiency issue- the process is complicating the judges' task of deciding appeals. A set word limit for skeletons and a limit on the number of documents presented might make a difference.

${ }^{11}$ For discussions see Briggs (2015) pp. 106 - 113 and Sime (2017) 51-69.

${ }^{12}$ As well as aggrieved with the other party. See Lobsenz (1985) p. 382. Robertson (2013) makes a similar point at p. 1274 .

${ }^{13}$ Whether the civil justice system's funding ought to be increased is a different question.

${ }^{14}$ Second appeals from the County Court will be heard in the Court of Appeal. Second appeals from Masters will be heard by the Court of Appeal. Second appeals from High Court Judges will go to the Supreme Court and be subjected to the threshold test of that Court.

${ }^{15}$ What a litigant thinks is justice, may not be justice according to the law. No lower court decision can be said to be the final word on what is just. The Supreme Court may rely upon the Practice Statement of 26 July 1966 (Practice Statement (Judicial Precedent) [1966] 1 WLR 1234- see Austin v Mayor etc of L B of Southwark [2010] UKSC 28 at paragraphs [24]-[25].

${ }^{16}$ See Pound (1941) p. 379.

${ }^{17}$ See Lord Hoffmann on killing the parties with kindness in Piglowska v Piglowski [1999] 1 W.L.R. $1360(H L)$ at p. 1373. Notably absent from Lord Hofmann's dicta is the process cost to the system of allowing the appeal to reach such a high level.

${ }^{18}$ This is nothing new, see Polden (2010) pp. 816-817. The names ae different but the stories are recognisable.
} 
'in the end you must accept what has been decided. Enough is enough.'19

\section{Vertical and Horizontal Relationships}

Richard Nobles and David Schiff ${ }^{20}$ have noted that the appeals structure creates both a vertical $^{21}$ relationship and a horizontal ${ }^{22}$ one. The appeal court supervises and holds the lower court to account. ${ }^{23}$ But the appeal court has to show some deference to the lower court on account of its detailed role in fact finding. Restraint is required, for the appeal court is already busy enough and if it intervenes too often, the trial risks becoming seen as a preliminary ruling rather than a final one. ${ }^{24}$ The horizontal relationship refers to the need of appeal judges to respect the decisions of courts of co-ordinate jurisdiction.

\section{The Pyramid of Appeals}

Following a trial, most parties will accept the first instance decision. If a party is dissatisfied he may seek permission for a first appeal. ${ }^{25}$ To gain that permission, the aggrieved party must pass the threshold test which comprises a merits test or, exceptionally, a compelling reason test. Where permission is granted and a first appeal is heard, most parties will accept that decision. It is only in those cases where the dispute remains contestable that a second appeal may be considered. Again, permission is needed ${ }^{26}$ but the threshold test is set at a higher level. ${ }^{27}$ Second appeals are subject to a combined merits and public importance test, although there is a 'compelling reason' escape hatch. ${ }^{28}$ The number of second appeals should be limited because the court can reject cases which are insufficiently important. But the effectiveness of the combined threshold test will depend upon two things: a willingness to reject cases which lack sufficient public importance and an austerity of approach to the use of the escape hatch. The civil justice system may now appreciate that it cannot eliminate all wrong decisions, but success here is reliant upon what individual judges do.

\footnotetext{
${ }^{19}$ Andrews (1994) p. 501 opens his chapter on Finality with an extensive citation from this case.

${ }^{20}$ Nobles and Schiff (2002) p.676.

${ }^{21}$ Nobles and Shiff (2002) p. 680.

${ }^{22}$ Nobles and Shiff (2002) p. 683.

${ }^{23}$ See Attorney General v Sillem (1864), 11 ER 1200 (HL) at p.1209. per Westbury LC For early comment on the tension between the US Supreme Court and state level courts see Wetherbee v Johnson (1817) 14 Mass 412 at p.420.,Parker C.J.

${ }^{24}$ Nobles and Schiff (2002) p. 685. A point also made in Bowman (1997)chap. 2, par. 4.

${ }^{25}$ CPR 52.6.

${ }^{26}$ CPR 52.7.

${ }^{27}$ The logic of narrowing the gate for second appeals is laid out clearly in $R$ (Sivasubramaniam) $v$ Wandsworth County Court [2003] 1 WLR 475 (CA)at paragraphs [48] and [54].

${ }^{28}$ CPR 52.7(2)(b).
} 


\section{The New Position}

As a result of the new CPR $52^{29}$ and the new Destination of Appeals Order, ${ }^{30}$ multi-track cases in the county court are subject to a new regime. The first appeal for these cases will now be heard by a High Court Judge and the Court of Appeal will now act as the second appeal court. ${ }^{31}$ The role of Circuit Judges as the destination of appeal from fast track cases remains but the role of the High Court is greatly increased. Few second appeals from County Court multi-track trials will pass over the raised second appeal threshold (CPR 52.7). The role of High Court judges in hearing appeals from multi-track cases is therefore going to be a significant one. As a general rule only those cases which are both meritorious and of importance will pass over the threshold for second appeals. ${ }^{32}$ Only exceptional cases will pass through the escape hatch.

\section{Who are Appeals for?}

The obvious beneficiary of an appeals process is the disappointed party. This will usually be the appellant alone but sometimes the respondent may also wish to cross- appeal. ${ }^{33}$ In the light of CPR 1.1(2)(e) we might also want to think about the impact of an appeal on other appellants. When cases are inappropriately admitted for appeal then waiting times may increase. ${ }^{34}$ So a decision to give permission to appeal may have a real impact on other cases. ${ }^{35}$ The appeal system also has to take into account the need for the civil justice system to stay within its budget and to fulfill its mission to do justice according to the law in a fair, timely and proportionate manner. A civil procedural reformer could legitimately hope that more money were available to pay for more appeal judges, ${ }^{36}$ but there are many demands upon the exchequer.

Society also has a stake in this. It is in society's interest that: disputes are resolved; the system operates as efficiently as possible; ${ }^{37}$ cases are processed; judges have the information they need ${ }^{38}$; and that justice is dispensed fairly. If this happens, there ought to be two benefits: reassurance of the public and a reduction in transaction costs. If the system works then people can be reassured that lawful behaviour pays, that unlawful behaviour costs and that wrongs are righted. The theory is that if law abiding behaviour is encouraged; settled

\footnotetext{
${ }^{29}$ In force $3^{\text {rd }}$ October 2016.

${ }^{30}$ Access to Justice Act 1999 (Destination of Appeals) Order 2016 (SI 2016/917) in force $3^{\text {rd }}$ October 2016.

${ }^{31}$ Under the AJA Destination of Appeals Order 2000 (SI 2000/1071) county court multi-track appeals went straight to the Court of Appeal.

${ }^{32}$ CPR 52.7(2).

${ }^{33}$ CPR 52.13(2)(b).

${ }^{34}$ Waiting times can also increase if too many meritorious cases are admitted to the appeal list. Briggs has not been able eliminate this systemic vulnerability.

${ }^{35}$ See Briggs (2015) pp. 106-113.

${ }^{36}$ See for example Briggs (2015) pars. 9.20 and 9.36.

37 Efficiency is not the main goal of the English civil justice system but it is an important subsidiary goal.

${ }^{38}$ This relates to the accuracy principle.
} 
arrangements will be adhered to; and the risks of commitment will be lowered. $^{39}$

\section{Policy, Practicality and Proportionality}

\section{Is there a Constitutional Context to Appeals?}

In common law cases the appeal court makes $\operatorname{law}^{40}$ in overturning or extending the existing case-law. New principles emerge or rather are developed by the judges. ${ }^{41}$ Allowing for the fact that not all appeals will be of wider significance, a proportion of the first appeal court's work may and the majority of the Court of Appeal's work should involve important matters of principle or practice.

Harlon L Dalton reminds us that there is an important constitutional context to the appeal process. He makes three points.

First, that appeals enable the governed to participate in the process of government through engaging the sovereign in the process and being engaged with the sovereign in that process $;^{42}$ Robertson adds that the appeal process goes to human dignity - concerning a litigant's experience of fairness, having a greater say in their destiny, and not having their fate decided by one judge. ${ }^{43}$

Dalton's second point is that appeals are important because of the values that they uphold, ${ }^{44}$ values which are 'external' to process and worthwhile in their own right -duties and rights matter and that the checking or corrective element of the appeals process reinforces that.

Lastly, Dalton says that the exercise of filtering out appeals, is in its own right, an exercise of state power. It is worth commenting that change is being driven by a lack of resources ${ }^{45}$ i.e. the government has declined to increase the resources available to the judicial branch of the state.

What are Appeals for?

We start first with an American view. Roscoe Pound said ${ }^{46}$ that the scope of appellate work covered ${ }^{47}$ a review of the lower court's work and an authoritative finding of the law which would have precedential value.

\footnotetext{
${ }^{39}$ Where the risk of default is lowered, the costs of commitment are also lowered.

40 The judiciary is an arm of government. See for example Bingham (2010 pp. 45-46.

${ }^{41}$ See Reid (1972-1973) p.22.

${ }^{42}$ Dalton (1986) p. 70 n.31 and pp. 94-95. at p. 66-67

${ }^{43}$ Robertson (2013) pp. 1271-1273.

44 Dalton (1986) pp. 97,101-102. He speaks of criminal appeals but the point is of wider application. There are echoes here of Harlan J's concurring judgment in the case of In re Winship 397 US 358 (1970) at p. 372.

${ }^{45}$ See Briggs (2016) par. 9.6.

${ }^{46}$ Pound (1959) p. 603.

${ }^{47}$ Pound (1959) p. 607.
} 
In his book Appellate Procedure in Civil Cases, ${ }^{48}$ Pound spoke of the need for the correction of mistakes, and for the prevention of error. Why should there be such a need? Pound cited Ulpian who said,

'There is no-one who is not aware how frequently appeals are employed, and how necessary they are to correct the injustice or ignorance of judges. ${ }^{49}$

He then cited Blackstone, to show there had been a long established policy of quieting claims and supporting the individual's right not to be vexed by repeated attacks. ${ }^{50}$

Pound went on to say that it is always necessary to be able to correct the unfairness or unskillfulness of those who judge. ${ }^{51}$ This is true even at the higher levels for even appellate courts are capable of making mistakes. ${ }^{52}$

Pound lastly says that the possibility of review offers 'prevention not cure' because it acts as a stimulus to thoroughness in the lower court. Dalton points out that the way in which cases are handled can also 'foster party satisfaction., 53 This matters because the legitimacy of the court system depends, at least in part, upon the acceptance of its decisions. Dalton notes ${ }^{54}$ the impact of the appeal system on judicial morale, and how, as a side benefit, an ambitious judge may benefit. In England, Neil Andrews has also noted that the existence of higher courts gives an ambitious judge a way of getting noticed. ${ }^{55}$

We look now at the correction of error from the English perspective.

\section{On being wrong}

Similar views about error have been expressed in England. Lord Devlin said 'We delude ourselves if we think that it always produces the right judgment. Every system contains a percentage of error. ${ }^{56}$ The Briggs Interim Report $^{57}$ spoke of 'the inherent fallibility of human beings' which 'means that perfection can never be more than an aspiration.' A system is therefore required to correct mistakes. Finally we might cite $R$ (Cart) v Upper Tribunal [2011] UKSC $28^{58}$ where Lady Hale, accepting the reality of error, said,

\footnotetext{
${ }^{48}$ Pound (1941) p. 3. Pound was clear that 'double appeals are to be avoided as far as possible' at p. 392.

${ }^{49}$ Ulpian in Justininian , p. 137.

${ }^{50}$ Blackstone (1765) Vol 1. Book III.

${ }^{51}$ Pound (1959) p. 606.-7. There is a similar passage at Pound (1941) p. 4.

52 This latter point is of interest when considering the cost of limiting the number of appeals which may be brought.

${ }^{53}$ Dalton (1986) p. 66-67

${ }^{54}$ Dalton (1986) p. 68.

${ }^{55}$ Neil Andrews (1994) pp. 211-12.

${ }^{56}$ From an interview in 1970. This influential argument features in Woolf (1995) Chap. 4 paras. and 6 and in para [46] of Gregory v Turner [2003] 1 WLR 1149.

${ }^{57}$ Briggs (2015) para. 9.30 .

${ }^{58}$ (Cart) at para [56].For a review of Cart see Elliott and Thomas (2012) p. 297.
} 
'Clearly there should always be the possibility that another judge can look at the case and check for error.'

Jacob's classic The Fabric of English Civil Justice ${ }^{59}$ drew upon the work of Peter E Herzog and Delmar Karlen ${ }^{60}$ ('Herzog') who made the point that, ${ }^{61}$

'Courts like all other human institutions, make mistakes. Such mistakes may occur with respect to the facts, or with the applicable substantive law, or with respect to the procedure for resolving issues of facts or law.'

This statement of fundamentals is worth contrasting with the features

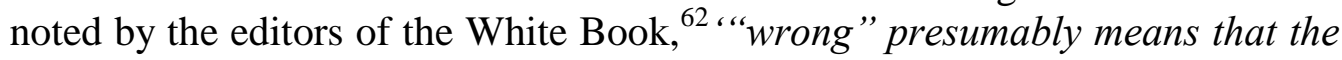
court below (i) erred in law or(ii) erred in fact or (iii) erred in the exercise of its discretion. To this, can be added the $2^{\text {nd }}$ limb of the new CPR 52.6 test, ${ }^{63}$ injustice arising from procedural irregularity. ${ }^{64}$

Sime points out that the error may arise because an established principle was ignored or the principles which were applied were in need of development or extension. ${ }^{65}$

\section{Judicial and Social Reasons}

Jacob went on ${ }^{66}$ to set out 6 core 'judicial and social reasons ${ }^{97}$ why an appellate procedure was required; corrective steps were needed:

a. to ameliorate an appellant's sense of grievance, ${ }^{68}$

b. to avoid any widespread public feeling that the civil justice system was unjust or unfair. Such steps worked to maintain public confidence;

Herzog had warned of the risk that 'bad decisions' might 'fester in the minds...of those directly aggrieved..' and in the minds of 'those who merely observe...creating resentment and insecurity. ${ }^{, 69}$

\footnotetext{
${ }^{59}$ Jacob (1987) p. 211.

${ }^{60}$ Herzog and Karlen (2014) chap.8.

${ }^{61}$ Herzog and Karlen (2014) p. 4.

${ }^{62}$ Civil Procedure 2005 volume 1 paragraph 52.11.3.

${ }^{63}$ Formerly CPR 52.11(3)(c).

${ }^{64}$ Which Sime (2017) p. 64.

${ }^{65}$ See Sime (2017) p. 65.

${ }^{66}$ Jacob (1987) p. 211-12. The importance of this list is taken as a starting point by Drewry et al (2007) pp. 20-21.

67 Andrews' (2013) pp. 418-419 helpful summary is on much the same lines as is Robertson (2013) p. 1225. Robertson deals with distributive aspects at pp. 1264-1267 and with expressive value at pp. 1266-1271. For a review of the social and political aspects of the appellate structure see Shapiro (1979) p. 629.

68 Avant la lettre, see paragraph 104 of the Report of the Committee on Administrative Tribunals and Enquiries Cmnd 218, 'Franks Report' (1957, HMSO, London).

${ }^{69}$ Herzog and Karlen (2014) p. 4
} 
c. to ensure that the outcome was both right and in accordance with justice;

d. to require the judiciary to exercise care in the performance of its role, 'in a proper and not arbitrary way;'

Sime's insight is that the appeal process keeps the whole judicial system honest for corrupt or biased decisions will be overruled. ${ }^{70}$ Or as the Franks Committee more prosaically put it, 'the existence of a right of appeal is salutary and makes for right adjudication. ${ }^{, 71}$

e. to allow the appeal court to express the law, offering clarification where required thus producing a socially responsive 'uniform system of law' developed in 'a harmonious and consistent manner'. 72 This is especially necessary because of the role that precedent plays in a common law system;

f. to allow more judges of greater experience to focus upon the issue being appealed.

Here, Jacob followed Herzog who had talked of the appeal judges being 'more mature and more experienced' and having 'a narrower focus and function' being 'less pressed for time' and 'able to devote a greater amount of deliberation and reflection to critically important issues. ${ }^{73}$

To this, Dalton adds ${ }^{74}$ the role that an appeal court plays in maintaining consistent practice amongst geographically dispersed courts and judges. The same point was made by Herzog who spoke of 'some central body to expound clarify and harmonize' the law.

\section{Does Procedural Fairness require an Appeal?}

In England and Wales the right to appeal is not constitutionally recognised but is conferred by statute. Article 6 of the European Convention on Human Rights 1950does not require that an appeal be offered but says if an appeal is offered, the process should comply with established procedural standards. As was said in Delcourt v Belgium [1970], ${ }^{76}$ '...the Convention does not...compel the Contracting States to set up courts of appeal. ${ }^{, 77}$ In the United States, whilst

\footnotetext{
${ }^{70}$ See Sime (2017) p. 51.

${ }^{71}$ Franks (1957) par. 104.

${ }^{72}$ Note (1977-1978) looks at the challenges to harmony and consistency in the context of appeals in the US.

${ }^{73}$ Herzog and Karlen (2014) p. 4. See also Lobsenz (1985) pp. 382-383.

${ }^{74}$ Dalton (1986) p. 69.

${ }^{75}$ Herzog and Lanker (2014) p. 5. A similar point is made at Franks (1957) pars. 104, 115.

${ }^{76}$ Delcourt v Belgium [1970] ECHR 2689/65 at paragraph [25].

${ }^{77}$ The Court of Appeal referred to this point in Ebert v Official Receiver (No.2) [2001] EWCA Civ 340 at paragraph [12]. Buxton L.J. went so far as to describe the legal point involved as being a trite one. A similar point was made in the US in Griffin v Illinois 351 US 12 (1956) pp. 24-25 per Frankfurter J. Griffin is dealt with in more detail at f/n 79 infra.
} 
it might be thought that the right of appeal has constitutional status, it is settled that it does not. ${ }^{78}$ Nevertheless there seems to be a general sense that 'the right to appeal... is a fundamental element of procedural fairness. ${ }^{, 79}$ As Robert Leflar says,

'the right is a protection against error, prejudice, and human failings in general[...] Justice and good law are needed for little cases as well as for good ones[...] One appeal is enough, but one should be allowed in almost any case'.

Put another way, one might say that the appeal process is the guarantee that efforts will be made to deliver a party's Article 6 rights. ${ }^{81}$

\section{Process Costs, Error Costs and Perfectionism}

Is it appropriate to restrict rights of appeal? There are three supportive arguments in favour of the post CPR reforms: that a reduction in cost justifies an increase in the error rate; that there is no absolute right to a correct outcome; and that, as perfection is unattainable, the proper question is what level of imperfection is to be tolerated.

In 1970 Lord Devlin said,

'Every system contains a percentage of error; and if by slightly increasing the percentage of error, we can substantially reduce the percentage of cost, it is only the idealist who will revolt. ${ }^{82}$

The Briggs Interim Report ${ }^{83}$ says,

Rights of appeal are not necessarily to be equated with a right of a litigant to some theoretically correct outcome to their dispute... The perfect can be the enemy of the good, and theoretically perfect but very slow justice can be worse than timely, but slightly rough, justice for everyone. ${ }^{, 84}$

\footnotetext{
78 See eg. Wiscart v D'Auchy (1796) 3 US 321 per Elsworth CJ at p. 329; McKane v Durston153 US 684 (1894) at p. 687; Griffin v People of the State of Illinois (1956) 351 US 12, 76 s Ct. 585; for a view of and literature on this issue from a criminal perspective see Cavallaro (2002) p. 943.

${ }^{79}$ ABA Commission on Standards of Judicial Administration: Standards Relating to Appellate Courts section 3.10 commentary at 12. (1977) Cited in Dalton (1986) p. 66.

${ }^{80}$ Robert Leflar, Internal Operating Procedures of Appellate Courts 4, 9-10 (1976) ABA cited in Dalton (1986) p. 66.

${ }^{81}$ For a similar approach but with different language see Young v Konz 88 Wash 2d 276 (1977)

(Supreme Court of Washington) per Hunter J at p. 280.

${ }^{82}$ Sime (2017).

${ }^{83}$ Briggs (2015) para 9.30.

${ }^{84}$ Samaha (2006-2007) p. 603-604 makes similar points. Samaha variously refers to 'undue process' in the sense of too much process and 'optimal process' which he considers as 'an impractical goal' (p. 647) and to cause unjustifiably high process costs (p. 648). Samaha notes
} 
Briggs highlights the conceptual distinction between a right to seek correction by appeal, effectively a process entitlement, and a right to a correct outcomeregardless of cost. Further, he points notes the resource of impact of the latter. Picking up again on the question of perfectionism, Briggs also notes ${ }^{85}$ 'there comes a point where the route towards supposed perfection becomes so demanding of resources that a line has to be drawn'. The cost in money, timeand effort of eliminating error costs imposes another cost, the process cost. ${ }^{86}$ Only recently, Stuart Sime has said, 'Obviously the Court of Appeal aspires to the dispensing of perfect justice. Ultimately, however, when it comes to the deployment of resources a line does have to be drawn. ${ }^{, 87}$

As Cass Sunstein says 'Decision costs are the costs of reaching judgments. Human beings incur these costs in all contexts...In the legal setting decision costs are faced by both litigants and courts ${ }^{, 88}$ to which we would add 'and by society.' In our context, the decision cost (which we call the process cost) is the cost of dealing with an appeal. ${ }^{89}$ The process cost is paid by all those participating in the litigation, including the court.

Put shortly, there is a danger of excessive process being imposed to avoid inadequate process. ${ }^{90}$ What Briggs and Bowman were trying to achieve was to strike the balance between limiting the cost of error and limiting the costs of error elimination through the appeals process. Samaha shows ${ }^{91}$ how process drives cost: in our case, in terms of the parties; the material put before the court, and the arguments advanced. Even the notion of what amounts to justice may be controversial, one person's search for justice being another person's financial burden. ${ }^{92}$ Process-driven cost might mean that to cure a backlog of cases (where the process cost is a loss of time) it is necessary to employ more judges (where the process cost is a financial one). ${ }^{93}$

As a result of this, says Samaha, human dignity ${ }^{94}$ issues can take second place to resource issues. Further, not making a decision on appeal may still have a cost, for where the court declines one case,it may 'export' decision costs to other people, including litigants and judges in subsequent cases. ${ }^{95}$

Devlin's view about the need to weigh up different kinds of cost was not only current in England and Wales. In the US case of Matthews $v$ Eldridge

how the same procedure can be seen to add process safeguards at the same time as adding costs (p. 649).

${ }^{85}$ Briggs (2015) para 9.30 .

${ }^{86}$ On this generally see Samaha (2006-2007).

${ }^{87}$ Sime (2017) p. 54.

${ }^{88}$ Sunstein (1996-1997) p. 16.

${ }^{89}$ See Samaha (2006-2007) p. 616. In this article we have concentrated upon the process costs relating to the appeal process.

${ }^{90}$ Samaha (2006-2007) p. 605.

${ }^{91}$ Samaha (2006-2007) pp. 616, 617

${ }^{92}$ Samaha.(2006-2007) p. 618.

${ }^{93}$ See Samaha (2006-2007) p. 620. See also Briggs (2015) paras. $9.10-9.11$.

${ }^{94}$ Samaha (2006-2007) p.652.

${ }^{95}$ Sunstein (1996-1997) p. 17. 
$(1976)^{96}$ the Supreme Court had to consider the ambit of the constitutional due process clause. Justice Powell laid down a three stage test ${ }^{97}$ requiring consideration of the:

(i) the impact on the litigant;

(ii) the balance of the risk against the protection offered; and

(iii)the impact upon the public purse and public administration. ${ }^{98}$

However one looks at it, the appeals process has resource implications for the litigants, the system and for society. ${ }^{99}$

In Part 3 we go on to look at steps taken to promote efficiency in first appeals. We will commence with the question of rerouting.

\section{First Appeals - The New Regime}

Rerouting of First Appeals ${ }^{100}$

Arrangements have been put in place to reroute first appeals from the County Court. to reduce the number of first appeals coming into the Court of Appeal. Section 56 of the Access to Justice Act 1999 allows the Lord Chancellor to specify alternative destinations for appeals. This is referred to as rerouting. ${ }^{101}$

Rerouting has been accomplished via the Access to Justice Act 1999 (Destination of Appeals) Order 2016. Article 5 deals with appeals from the Circuit Judge in the County Court, routing them away from the Court of Appeal and towards to the High Court.

On the question of rerouting, the Court of Appeal's proposals in May 2016 had said that

'the emphasis in [the court's]work should be upon providing guidance for lower courts and the public on issues of law, rather than simply determination of run-of-the-mill cases. ${ }^{102}$

\footnotetext{
${ }^{96} 424$ US 319, 96 S Ct 893. The case is discussed in Lobsenz (1985) p. 380; Robertson (2013) pp. 1241-1245, and Samaha (2006-2007) p. 642.

${ }_{97}$ Matthews $v$ Eldridge, ibid. at p. 901.

${ }^{98}$ This kind of balancing of risk and reward will be familiar to common law tort lawyers from the test described in Stokes $v$ Guest, Keen and Nettlefold (Bolts \& Nuts) Ltd [1968] 1 WLR 1776 at p. 1783.

${ }^{99}$ Robertson (2013) would take a different view of where the balance ought to be struck.

${ }^{100}$ The relevant legislation governing appeals is to be found in different places: Sections 54(1) and 55 Access to Justice Act 1999; Section 16 Senior Courts Act 1981; and Section 77 County Courts Act 1984.

${ }^{101}$ Consultation Exercise (2016) p. 5.

102 See ConsultationExercise (2016) pp. 40-41. Fallon (1993) p. 369 notes the tendency of the appellate courts to concentrate upon cases which will have systemic effect due to the hierarchic nature of appeals.
} 
The justification for this was that offering an appeal to the High Court would be proportionate in judicial resource and legal costs terms; and the case would have been checked by an appeal court, albeit not the Court of Appeal.

\section{Seeking Permission}

Under the old and new CPR 52, permission to appeal was and is a precondition (the old CPR 52.3(6) and the new CPR 52.6 respectively). This approach filters out weak cases by subjecting them to an initial consideration or checking process. It is in this context that Woolf's suggestions in his Final Report make sense. He seems to have envisaged ${ }^{103}$ that a party whose application for permission had been turned down by the appeal court ought to feel that their case had in fact been 'looked at' i.e. checked by the appeal court even if not subjected to a full review.

\section{Practicalities of First Appeals}

First appeals from multi-track County Court trials will no longer go to the Court of Appeal. Those applications for permission which were formerly dealt with by a single Lord Justice of Appeal will now be considered by a High Court Judge instead. This will cut the workload of the Court of Appeal ${ }^{104}$ given the amount of time spent by the judges of that court in considering permission to appeal applications. ${ }^{105}$ The rerouting of appeals means that multi-track appeal from the County Court will not enter the Court of Appeal's list at all thus, hopefully, reducing the waiting time for other cases the current backlog. ${ }^{106}$ At present, the number of appeals being handled by the High Court appears under control and so, at least initially, parties may expect to get a faster appeal hearing in the High Court. But the problem is simply being shifted from one court to another and, as more work goes into the High Court, the listing time for appeals may lengthen there. ${ }^{107}$ Given that appealing to the High Court is likely to be less costly than to the Court of Appeal, parties may consider that it is worth at least applying for permission to appeal or perhaps proceeding to a full appeal, in which case the number of applications for permission may continue to rise. ${ }^{108}$

\footnotetext{
${ }^{103}$ Woolf, (1996) chap. 4, paragraph 1. Nobles and Schiff (2002) bring this point out at p. 687.

${ }^{104}$ Although, curiously, the number of appeals in 2016 fell by $18 \%$ on the previous year see Civil Justice Statistics Quarterly,England and Wales, January to March2017 (provisional) and Royal Courts of Justice 2016, at https://www.gov.uk/government/uploads/system/uploads/ attachment_data/file/616571/civil-justice-statistics-quarterly-jan-mar-2017.pdf (accessed on $5^{\text {th }}$ June 2017).

${ }^{105}$ See Briggs (2015) paras. 9.3 and 9.22.

${ }_{106}$ Briggs (2015) par. 9.22. The backlog is set out at Consultation Exercise (2016).

${ }^{107}$ Unless more work is pushed down to the County Court in return.

${ }^{108}$ Given the historic rise in the volume of permission applications in the Court of Appeal, this has to be a reasonable prospect.
} 


\section{Second Appeals - The New Regime}

\section{Second Appeals}

For the Court of Appeal, granting permission has been a major source of problems in its own right ${ }^{109}$ because of an apparent lack of confidence in decisions made without a hearing by a single lord justice. Here the instinct for en-banc procedure works against the court.

Jack Jacob had thought ${ }^{110}$ that the underlying logic of the system was parsimonious. Appeal courts should respect the trial process and preserve finality wherever possible. This view was somewhat at odds with reality, for, as late as December 1998, the Court of Appeal had a very generous admissions policy, taking into account the very low success threshold requirement and the multiple exceptions for weak cases. More impressive wasJacob's statement that parties should be content with a decision because 'there $i$ s no social or political need to provide an open avenue' for appeals 'except within somewhat strict limits.'

From $2^{\text {nd }}$ May $2000^{111}$ there were specific requirements for permission for a second appeal which were structured around questions of importance and compelling reasons. ${ }^{112}$ Even the latest changes retain this broad basic structure, albeit that specific attention is now given to the reality of the prospects of success. ${ }^{113}$

\section{Bowman and before}

In February 1997, Lord Woolf said ${ }^{114}$ that leave to appeal would only be refused if there was 'no realistic prospect' of success. The use of the term realistic here meant that 'a fanciful prospect or unrealistic argument' was not enough.But a party without a realistic prospect of success could be granted permission where it was 'in the public interest' to examine it, or where 'the law require [d] clarifying;'

In September 1997 Sir Jeffrey Bowman's Committee ${ }^{115}$ concluded that appeals should disposed of in a 'proportionate" ${ }^{\text {,16 }}$ manner. The norm would be

\footnotetext{
${ }^{109}$ See e.g. Briggs (2015) paras. 9.1, 9.3, 9.22-9.32.

${ }^{110}$ Jacob (1987) pp. 231-2. Jacob also placed importance upon the deference which the appeal court would display towards the factual findings of the trial judge.

${ }^{111}$ When CPR 52 came into force.

112 The old 52.13(2).

${ }^{113}$ The new CPR 52.7 failed to adopt the sterner test of a 'substantial prospect.' This was not the Court of Appeal's preferred approach.

${ }^{114}$ Smith v Cosworth Casting Processes Ltd [Practice Note] [1997] 1 WLR 1538. The importance of this case is confirmed in Bowman (1997) chap. 3 at paras. The evolution of this approach can be traced through Practice Direction,Court of Appeal: Leave to Appeal and Skeleton Arguments) [1999] 1 WLR 2 at paragraph 10 and Practice Direction, Court of Appeal (Civil Division) [1999] 1 WLR 1027 CA, paragraphs 2.2.1 and 2.8.1. For the history of these changes see Scott (1999) pp. 287-290.

${ }_{115}^{115}$ Bowman (1997). For comment on this Report see Jacob (1998).

${ }^{116}$ Bowman (1997) chap. 2, par.14.
} 
only one appeal, with exceptions where appropriate. ${ }^{117}$ Such restricted approach would meet the 'need for certainty, reasonable expense and proportionality'118 and keep 'uncertainty and delay...to a minimum.'119 Appeals were not 'an automatic further stage in a civil case.' It was for the trial judge 'to dispose of the action. ${ }^{120}$ Bowman proposed that 'the assumption should be that the court...has made the correct decision. ${ }^{121} \mathrm{But}$ if there was to be no automatic right of appeal,a party should be able to have the case 'looked at by a higher court so that it can consider whether there appears to have been an injustice.' Only if that court saw an appearance of injustice would an appeal be permitted. ${ }^{122}$ The permission stage therefore had the dual function of filtering and offering reassurance through the checking process. ${ }^{123}$

This was a significant step in the Court of Appeal's thinking, akin to the American approach of placing attention 'on whether decision making structures are adequate to achieve, on average, a socially tolerable level of accuracy in the level of law to fact. ${ }^{124}$ The difficult question for Bowman was how 'searching' the appeal process should be. ${ }^{125}$

From $2^{\text {nd }}$ May 2000, Part 52 of the CPR was in force. CPR 52.3 (6) introduced the familiar 'permission to appeal will only be given' formula in the distinct limbs of 'real prospect of success' or 'some other compelling reason'.

\section{The Old CPR 52.13}

Prior to $3^{\text {rd }}$ October 2016 the test for permission to get to the Court of Appeal on second appeals was set out in CPR 52.13(2). The Court of Appeal would not give permission ${ }^{126}$ unless it considered that appeal concerned 'an

\footnotetext{
${ }^{117}$ Bowman (1997) chap. 4, par.6.

${ }^{118}$ Bowman (1997) chap. 2, par.15.

${ }^{119}$ Bowman (1997) chap. 2, par.7.

${ }^{120}$ Andrews (2013) p. 416, puts it thus 'Trial is a luxury...an appeal should be regarded as exceptional.'

${ }^{121}$ Bowman (2013) chap. 2 par. 4.

122 Bowman (2013) chap. 2 par. 5. Fallon (1993) p. 330, notes a reverse approach in US substantive due process cases where a lack at the earlier stage of a process is supplied at the later stage. The overall point is that in the English jurisdiction there has to be both a sufficient quantity and quality of process. In most cases the trial before the lower court will meet this standard.

${ }^{123}$ Page 3 of Bowman's covering letter to the Report (dated September 1997 and written to the Lord Chancellor) [Bowman (2013) makes the identical point]. This check is an important if under emphasised element of the process.

${ }^{124}$ Fallon (1993) p. 311. The argument is that without some cut-off the volume of court work would be too great.

${ }^{125}$ Bowman (2013) concluded that one level of appeal will allow for scrutiny of an appropriate depth. Availability under the current CPR 52 is impacted by the quality filters of CPR 52.6 and 52.7 which govern when it is appropriate to intervene. Fallon (1993) pp. 333, 336 speaks of a 'minimally adequate availability...of review.'

${ }^{126}$ Refusal of permission to appeal is final -Moyse v Regal Mortages Ltd Partnership [2004] EWCA Civ 1269 at paragraphs [23] and [31].
} 
important point of principle or practice'; or that there was 'some other compelling reason' for the appeal to be heard.

The background logic to the post CPR introduction of CPR 52.13 was explained by Brooke LJ in Tanfern Ltd. $v$ Cameron-Macdonald [2000] 1 W.L.R. $1311(C A)$ as being that ${ }^{128}$ it was for Parliament to provide resources. Parliament was entitled to control expenditure. Section 54 of the Access to Justice Act 1999 was intended to achieve what Parliament wanted. ${ }^{129}$ Appeals would be rare and judges would concentrate upon first appeals. Many appellants would have to accept that, ordinarily, 'no' at the first appeal hearing meant 'no'. 130

The threshold test had two limbs.

\section{Importance}

In Eba v Advocate General for Scotland [2011] UKSC 29, ${ }^{131}$ Lord Hope PSC, said that the importance test looked at what was of general importance. The important point of principle or practice ought to be a new point and not an already established one - Uphill v BRB (Residuary) Ltd [2005] EWCA 60. ${ }^{132}$ Lord Clarke said in $R$ (Cart) v Upper Tribunal [2011] UKSC $28,{ }^{133}$ that the test worked well, enabling the husbanding of resources but leaving the door open, for when 'something has gone seriously wrong.'

\section{The Escape Hatch}

If the case did not raised an important point of principle or practice, then it was for the would-be appellant to show a compelling reason for a second appeal- and so use the escape hatch. ${ }^{134}$ This excluded cases that were only 'properly arguable' or had only 'real prospect' - Tanfern Ltd v CameronMacDonald (Practice Note) [2000] 1 WLR 1311. ${ }^{135}$

Dyson LJ considered the meaning of 'some other compelling reason' in Uphill v BRB Residuary [2005] EWCA Civ 60. ${ }^{136}$ He said that:

\footnotetext{
127 This test, replicates the provisions of s55(1) of the Access to Justice Act 1999.

${ }^{128}$ Tanfern paragraphs [41]-[46]. Zuckerman (2013) is especially good on the permission test up to 2013. Paragraphs 24.135 - 24.138 and 24.165 - 24.179 repay study.

${ }^{129}$ Tanfern paragraph [41].Note here the financial subordination of the judicial arm to the executive arm of government although the language refers to 'Parliament'.

${ }^{130}$ In this context Brooke LJ was speaking, in particular, of litigants in person - Tanfern paragraph [43].

${ }^{131}$ Eba at paragraph [48].

${ }^{132}$ Uphill, per Dyson L.J., at paragraph [18].

${ }^{133}$ Cart paragraph [104].

134 Just as there was in CPR 24.2(b) and CPR 13.3 (b); the 'compelling reason' or 'good reason' tests respectively.

${ }^{135}$ Tanfern paragraph $[42$.

${ }^{136}$ Uphill paragraph [24]. Uphill was considered in Esure Insurance Ltd $v$ Direct Line Insurance Plc [2008] EWCA Civ 842 at paragraph [35].
} 
(a)the prospects would ordinarily need to be 'very high' as a necessary condition of granting permission ; but

(b)a strong case was usually not a sufficient condition. There would still need to be a compelling reason.

He went on to say that very high prospects would not be required if the reason was compelling enough.

The implications of all these were clear: a second appeal might be refused even if an appeal court concluded that the lower court was wrong, unless the threshold test was satisfied. ${ }^{137}$

Further guidance has been provided by the Supreme Court. In Ebav AG for Scotland [2011] UKSC 29, ${ }^{138}$ Lord Hope PSC said that the term compelling would,

'include circumstances where it was clear that the decision was perverse or plainly wrong or where, due to some procedural irregularity, the [party] had not had a fair hearing at all.'

In Cart, Lord Dyson had said, ${ }^{139}$

'[...] the second limb of the test ("some other compelling reason") would enable the court to examine an arguable error of law [...] which cries out for consideration by the court [...]'

Reluctant to be definitive in the face of potentially differing circumstances, Lord Dyson did highlight 'wholly exceptional' failures of procedural fairness and errors of law with 'truly drastic consequences'. Both of these indications need to be read in the light of Cart being a judicial review case.

We conclude our review by looking at the new CPR 52.7 which now governs second appeals to the Court of Appeal.

\section{The New CPR 52.7}

The changes to the rules came into force on $3^{\text {rd }}$ October $2016 .{ }^{140}$ The explanatory memorandum, curiously, refers neither to the Briggs proposal to

\footnotetext{
${ }^{137}$ The Court of Appeal has said that some flexibility was required in the way in which CPR 52.13(2) is interpreted - Cramp v Hastings BC [2005] EWCA Civ 1005, at paragraphs [64][67]. In Cramp there appeared to be a developing practice of county court judges making decisions which did not take account of established authority. For comment on Uphill and Crampsee Jenns (2006) pp. 439-450. Bowman had envisaged the grant of permission where temporary problems had arisen or where case management guided was required: see Bowman (1997) chap. 4 par. 21.

${ }^{138} \mathrm{Eba}$ at paragraph [48] a Scottish case.

${ }^{139}$ Cart at paragraph [131]. The boundaries of what might amount to a 'compelling reason' have not been fully sketched although it can be said it must be compelling from a legal perspective - R (PR Sri Lanka v Sec State for the Home Department [2011] EWCA 988.

${ }_{140}$ See Civil Procedure (Amendment No.3 Rules 2016 (SI 2016/788) and rule 10 thereof.
} 
insert a merits test nor to the opposition to setting the level of that test as ' $a$ substantial prospect. ${ }^{141}$

The draft rules had provided that, for second appeals, permission would only be granted where 'the court considers that the appeal would have a substantial prospect of success" ${ }^{142}$ This was intended to mean it is 'seriously arguable that an error has been made (and not merely arguable so that it cannot be said to be fanciful). ${ }^{143}$ The rationale was to concentrate the Court of Appeal's 'resources...on the cases which most merit review at an appellate level.' 144 This would mean putting the resources into 'the cases where it really matters. ${ }^{145}$

That proposal was not reflected in the new rules- undoubtedly a significant opportunity missed but perhaps a sensible compromise given that first appeals in the Court of Appeal would comprise High Court Appeals - by definition not run of the mill cases. Further, keeping the same basic wording for first and second appeals does, at least, allow for a consistent approach to be taken.

The new rule provides, at CPR 52.7(2),

'The Court of Appeal will not give permission unless it considers that-

(a) the appeal would-

(i) have a real prospect of success; ${ }^{146}$ and

(ii) raise an important point of principle or practice; or

(b) there is some other compelling reason for the Court of Appeal to hear it.'

The continuity with the escape hatch wording from the old CPR 52.13 means, ordinarily, that the prospects will need to be 'very high' (- Uphill) for the escape hatch to open.

\section{Implications}

Restricting the right to appeal may be justified as:

(a) weeding out weak claims;

(b)protecting people from themselves (the Piglowska approach);

(c)protecting the system from the people (the Bowman and Briggs approach); and

(d)protecting society from an overly demanding system.

\footnotetext{
${ }^{141}$ See Consultation Exercise (2016) pp. 5, 7 where it is said that 'the CA believe that...' This is a very strong statement.

${ }^{142}$ Consultation Exercise (2016) p. 16, proposed CPR 52.3D.

${ }^{143}$ Consultation Exercise. p. 7.

${ }^{144}$ Consultation Exercise. p. 7. As Blackstone (1765) puts it is appropriate to give more 'time and circumspection' in cases 'where the suitors have valuable and permanent rights to lose'. He equates speedy justice with autocratic rule. We might equate it with efficiency.

${ }^{145}$ Consultation Exercise. p. 7.

${ }^{146}$ Added by new CPR 52.7.
} 
Although this may seem harsh the system, as it was, could not cope. An increase in demand together with a lack of money for extra staff has been the driving force behind the changes to CPR 52: the government, by withholding extra funding, has effectively required the civil justice system to tolerate increasing delays or impose a rationed approach to appeals. There is some logic to this. ${ }^{147}$ Demand for the services of appeal judges continues to rise. Public funds are limited. No branch of government is able to act outside the constraints of limited funding. ${ }^{148}$ Therefore the civil justice system has either to meet increasing demand through increased efficiencies or fall short of its aspirations by doing less. The government might argue that these are exactly the sorts of tough decisions that managers in the Health Service take on a daily basis. Procedural justice is difficult to measure using the yardstick of money, but it costs real money to deliver it.

We conclude that:

(a) An appeal court focuses upon what has gone wrong. It should have the time, expertise and experience to address the problem being scrutinised;

(b) In the case of the Court of Appeal, it is able to bring at least two minds to bear on any particular problem;

(c) Because error is always a possibility, it is appropriate to have some mechanism to attempt correction and so reduce error costs. In addition the existence of an appeal process encourages the lower courts to be diligent and allows the system to police itself;

(d) But perfection is not possible because of the process cost of an appeal and because judges may ultimately disagree about the correct answer;

(e) All aggrieved litigants may ask for a check to be carried out concerning the decision in their case;

(f) In the first place, that check amounts to a review of the papers;

(g) Where the appeal court thinks that the limited check reveal that an appeal may have merit or that a full review is really needed then the case will proceed to a full appeal;

(h) A by-product of the availability of this process should be a continued confidence in the civil justice system;

(i) The norm that 'one appeal is enough' will only be realised if second appeal courts apply the threshold test properly. The idea that only cases of importance should reach the top of the appeals pyramid is a corollary of the one appeal theory. Making this a norm will require a consistent hardening of judicial attitudes; an acceptance by all appeal judges that the checking process is a valuable justice-enabling provision in its own right, and a shared confidence within the lower and higher courts thata single appeal amounts to the completion of justice. ${ }^{149}$ If this point is reached then

\footnotetext{
147 The duty placed on the Lord Chancellor is not an absolute one. Section 3(6) (b) of the Constitutional Reform Act 2005.

${ }^{148}$ This was precisely the point made by the Court of Appeal in Uphill.

${ }^{149} \mathrm{We}$ wonder to what extent this philosophy of appeals has the widespread acceptance that it will need to be effective.
} 
cases which would have received permission previously will now be refused permission;

(j) The High Court will of necessity make the running in developing or applying the law for smaller cases, as permission for a second appeal will not readily be granted;

(k) The most important first appeals will emerge from the High Court and will continue to be deal with by the Court of Appeal. Hearing these kinds of appeals is a significant part of the Court of Appeal's work. As a consequence of rerouting, the volume of appeals in the Court of Appeal should therefore reduce;

(1) First appeals from circuit judges will now be heard by the High Court. The volume of appeals in the High Court will therefore increase substantially;

(m) Multi-track appeals will be conducted in most cases by High Court or former High Court judges. ${ }^{150}$ It remains unclear to what extent these appeals will be directed towards judges with relevant experience;

(n) The attenuated procedure available for first appeals in the County and High Courts is likely to encourage parties to see whether permission to appeal will be granted;

(o) All second appeals from the County Court and the High Court will be heard by Court of Appeal provided the threshold of importance and merits is crossed or the test of compelling reasons is met. It is envisaged that many cases will not satisfy either permission test;

(p) The Court of Appeal will continue to give guidance and make law in those second appeals which warrant it;

(q) Appeal courts are empowered and constrained by the vertical nature of appeals. The vertical axis means that appeal courts both correct the errors of lower courts and have to show an appropriate degree of deference. Such deference operates to preserve the resources of the Court of Appeal for when they are needed.

\section{References}

- Note (1978) "Securing Uniformity in National Law: A Proposal for National Stare Decisis in the Courts of Appeals" in Yale L.J. Vol. 87(6): 1219-1246.

Andrews, N. (1994).Principles of Civil Procedure. Sweet \& Maxwell, London.

Andrews, N.H. (2000). "A New System of Civil Appeals and a New Set of Problems" in Cambridge Law Journal, Vol 59(3): 464.

Andrews, N. (2013). Andrews on Civil Processes. Intersentia, Cambridge.

Bingham, T. (2010). The Rule of Law. Allen Lane, London.

Blackstone, W. (1765).Commentaries on the Laws of England, Clarendon Press, Oxford.

Briggs, M., Lord Justice (2015).Civil Courts Structure Review: Interim Report, Judiciary of England and Wales.

\footnotetext{
${ }^{150}$ It seems unlikely that court would release judges to hear cases which are now, by definition, insufficiently important to be heard by a Court of Appeal judge.
} 
Briggs, M., Lord Justice (2016). Civil Courts Structure Review: Final Report, Judiciary of England and Wales.

Bowman, Sir Jeffrey (1997) Report to the Lord Chancellor: Review of the Court of Appeal (Civil Division). Lord Chancellor's Department.

Cavallaro, R. (2002)."Better off Dead: Abatement, Innocence and the Evolving Right of Appeal" in U Colo L Rev Vol. 73: 943

Civil Justice Statistics Quarterly, England and Wales, January to March2017 (provisional) and Royal Courts of Justice 2016, Ministry of Justice, London.

Consultation Exercise - Appeals to the Court of Appeal: proposed amendments to Civil Procedure Rules and Practice Direction (2016) Civil Procedure Rules Committee, London.

Clark, C.E. (1954). "The Evershed Report and English Procedural Reforms" in New York University Law Review Vol. 29:1046

Dalton H.L. (1986). "Taking the Right to Appeal (More or Less) Seriously" in Yale L $J$ Vol. 95: 62.

Drewry, G. et al (2007).The Court of Appeal. Hart Publishing.

Elliott. M. and R. Thomas (2012)."Tribunal Justice and Proportionate Dispute Resolution", in Cambridge Law Journal Vol. 71: 297.

Evershed, Sir Raymond (1953).The Final Report of the Committee on Supreme Court Practice and Procedure, Cmd 8878. HMSO, London.

Fallon Jr, R.J. (1993). "Some Confusions about Due Process, Judicial Review, and Constitutional Remedies" in Colum L Rev Vol. 93: 309.

Franks, Sir Oliver (1957). Report of the Committee on Administrative Tribunals and Enquiries, Cmnd 218. HMSO, London.

Herzog, P.E, and D. Karlen (2014).“Attacks on Judicial Decisions” in International Encyclopedia of Comparative Law(ed. Mauro Cappelletti),Vol. 16. Martinus Nijhoff Publishers, Leiden \& Boston).

Jenns, T. (2006). "Is it all Downhill for Second Appeals?" in Civil Justice Quartery, Vol 25: 439-4500

Jacob, Sir Jack (1987).The Fabric of English Civil Justice. Stevens \& Sons, London.

Jacob, J.M. (1998). "The Bowman Review of the Court of Appeal" in Mod L Rev. Vol. 61: 390

Justininian Digest, from Corpus Juris Civilis, the Civil Law tr. S P Scott (AMS Press New York reprint 1973, first published 1932)..

Lobsenz, J.E. (1985). "A Constitutional Right to an Appeal: Guarding Against Unacceptable Risks of Erroneous Conviction", in SeattleU.L. REV. Vol. 8: 375

Nobles, R. and D. Schiff (2002). "The Right to Appeal and Workable Systems of Justice" in Mod. L Rev. Vol 65: 676.

Polden, P. (2010). "The Courts of Appeal", chapter VIII of Volume XI of the Oxford History of the Laws of England, (William Cornish et al eds.). Oxford University Press, Oxford.

Pound, R. (1941).Appellate Procedure in Civil Cases. Brown \& Company, Boston.

Pound, R. (1959).Jurisprudence, Volume 5, West Publishing, St Paul, Min.

Reid, Lord James (1972-73). "The Judge as Lawmaker" in Journal of the Society of Public Teachers of the Law, Vol.12:.22.

Robertson, C. Burke (2013). "The Right to Appeal” in NCL Rev Vol. 91: 1219.

Samaha, A.A. (2006-2007). "Undue Process" in Stan L Rev, Vol. 59: 601

Scott. I.R. (1999).Note - "Permission to appeal in 'second tier' appeals" in Civil Justice Quarterly. Vol 18: 287-290.

Shapiro, M. (1979). “Appeal” in Law and Soc'y Rev, Vol:14: 629. 
Sunstein, C.R. (1996-1997). "Foreword: Leaving Things Undecided" in Harv L Rev Vol. 110(4): 16.

Sime, S. (2017). "Appeals after the Civil Courts Structure Review" in Civil Justice Quarteely, Vol. 36(1): 51-69.

Woolf, Lord Harry (1995).Access to Justice Interim Report. HMSO, London.

Woolf, Lord Harry (1996).Access to Justice Final Report. HMSO, London.

Zuckerman, A. (2013). Zuckerman on Civil Procedure. Sweet \& Maxwell, London. 